\title{
The population structure, age and growth of Luciobarbus callensis (Cyprinidae) in a man-made lake in the Maghreb (NE Algeria)
}

\author{
Fateh Mimeche ${ }^{1}$, Mohamed Biche ${ }^{2}$, Ana Ruiz-Navarro ${ }^{3}$ and Francisco J. Oliva-Paterna ${ }^{3, *}$ \\ ${ }^{1}$ Department of Agricultural Sciences, University of M'Sila, M'Sila, Algeria; e-mail: mimechefateh@gmail.com \\ 2 Department of Zoology and Forestry, National Agronomic Institute, El Harrach, Algiers, Algeria \\ ${ }^{3}$ Department of Zoology and Anthropology, University of Murcia, Murcia, Spain \\ * Corresponding author: fjoliva@um.es
}

Received: 3/4/13 Accepted: 26/7/13

\begin{abstract}
The population structure, age and growth of Luciobarbus callensis (Cyprinidae) in a man-made lake in the Maghreb (NE Algeria)

Knowledge of the biological traits of native fishes distributed throughout the Maghreb, e.g., Luciobarbus callensis, the target species of this study, is essential for assessing the status of these species and for improving their conservation. In this study, the age and growth characteristics of a population in a man-made lake showing temporal variations in ecological conditions and managed for agricultural purposes were investigated. The sampled population showed a wide range of ages and an age structure dominated by middle-aged cohorts $(4+-7+)$. Compared with stream populations, the studied stock was characterised by a large number of age groups. The annual growth of middle-aged fish was not great and decreased with longevity. The growth pattern was seasonal, consisting of a single growth period extending from the end of winter to spring, immediately prior to the reproductive period. Relative abundance showed slight differences between seasons. The highest values of somatic condition occurred immediately following the reproductive period. Most likely, the characteristics of the species were affected by the ecological variation of the reservoir and by the highly variable stream flowing into the reservoir. However, Luciobarbus callensis showed a high adaptability to these artificial systems.
\end{abstract}

Key words: Cyprinids, life history, population biology, reservoirs.

\section{RESUMEN}

Estructura poblacional, edad y crecimiento de Luciobarbus callensis (Cyprinidae) en un embalse del Magreb (NE, Argelia)

El conocimiento de las características biológicas de especies de peces nativos ampliamente distribuidos por el Magreb, como es el caso de la especie objetivo Luciobarbus callensis, resulta esencial para evaluar su actual estatus y priorizar en su conservación. En el presente trabajo se estudia la edad y el patrón de crecimiento de una población localizada en un embalse que presenta variaciones temporales en sus características ecológicas y presenta una dinámica de uso condicionada por las necesidades agrícolas. La población muestreada mostró un amplio ciclo de vida con una estructura de edad dominada por individuos de las cohortes de edad intermedia $(4+-7+)$. En comparación con otras poblaciones de la especie establecidas en ríos, nuestra población de estudio se caracterizó por un alto número de edades. El crecimiento anual observado en las cohortes de edad intermedia no fue elevado y decreció con la longevidad, a su vez, el patrón de crecimiento estacional se caracterizó por la presencia de un periodo exclusivo de crecimiento que incluyó el final del invierno y la primavera, justo antes del periodo reproductor. La abundancia relativa de la especie mostró ligeras diferencias estacionales y la condición somática presentó sus valores más elevados después de la reproducción. La especie presentó características biológicas probablemente afectadas por las variaciones ecológicas del embalse y por la dinámica de alta variabilidad ambiental del río que nutre dicho sistema. No obstante, Luciobarbus callensis refleja una gran capacidad para adaptarse a estos sistemas artificiales.

Palabras clave: Ciprínidos, estrategia de vida, biología poblacional, embalses. 


\section{INTRODUCTION}

Basic life history information is essential in the study and analysis of population performance and in both theoretical ecology and fisheries management (Wootton, 1998). Moreover, the study of biological traits is an important element of the overall description of a species, and this information is essential for the appreciation of the role of biodiversity in the functioning of ecosystems. In the case of native fishes, there is a general need to increase the knowledge of their biological traits because this information furnishes a necessary tool for conservation programmes (Cooke et al., 2012). Such information is lacking for particular areas, e.g., North Africa, and it is very difficult to accurately assess the status of a species and to make suitable management decisions in the absence of such information.

In biogeographic terms, the Maghreb ecoregion has a closer affinity with the Mediterranean part of the Palaearctic realm than with the other portions of Africa (Lévêque et al., 2008). Although it is generally not rich in freshwater fish species, it harbours an interesting diversity of cyprinid species. Barbels are the most common group in the region, representing more than $20 \%$ of the total number of fishes as well as approximately $60 \%$ of all of the region's endemic fish species (Doadrio, 1994; Azeroual et al., 2000; Lévêque et al., 2008; García et al., 2010; Kara, 2012). Moreover, the family Cyprinidae includes the greatest number of species used by humans of any family of fishes in this ecoregion. The species used by humans include the endemics, and at least $50 \%$ are known to be of socio-economic value (Juffe-Bignoli \& Darwall, 2012). One example is the target species of the current study, the Algerian barbel, an endemic species found commonly in aquatic environments in Tunisia and Algeria (Bacha \& Amara, 2007; Djemali et al., 2008; Kara, 2012; Ould-Rouis et al., 2012). Although it is not a primary source of food, it represents an important source of protein for the inhabitants of rural communities in these countries.
Despite the wide distribution of the Algerian barbel and the value of this species to humans, only a few studies have addressed its phylogenetic relationships, reproductive traits and various ecological features (Kraiem \& Pattee, 1988; Berrebi et al., 1995; Kraiem, 1996 and 1997; Doadrio et al., 1998; Aberkane \& Iguer-Ouada, 2011, Ould-Rouis et al., 2012). The existing data on the age and growth of this species are limited (Kraiem et al., 1986; Bouhbouh, 2002; OuldRouis et al., 2012), and information about its population biology remains scarce. The circumMediterranean Barbus s. str. forms a strongly supported monophyletic group composed of two barbel lineages (Machordom \& Doadrio, 2001), Barbus and Luciobarbus, which could be considered distinct genera in agreement with previous morphological data and recent DNA analysis (Kottelat \& Freyhof, 2007; Gante, 2011). Accordingly we use the name Luciobarbus callensis (Valenciennes) for the Algerian barbel in the present study as a synonym of Barbus callensis.

Our study presents the first data on the age composition and growth traits of a population of Luciobarbus callensis in the southern portion of its geographic range. The population inhabits a man-made lake with marked annual variation in water temperatures and volume. The objectives of the study were to provide information on the biology of this species; to analyse whether age and size structure, growth and somatic conditions differed among the seasonal periods; and to evaluate possible environmental effects on these growth traits. We hypothesised that the Luciobarbus callensis population using this man-made lake would most likely display features affected by the changing environment and influenced by the natural stream systems that flow into the lake. Because the population viability of several native species appears to be limited by engineering projects such as impoundment by dams and the creation of new limnetic systems, understanding the biology of the study species in this aquatic system can provide important tools for conservation programmes. 


\section{MATERIALS AND METHODS}

\section{Study area}

The present study was conducted in the K'sob reservoir (El-K'sob barrage), an old man-made lake located in a semiarid region of the Saharan Atlas National Park in the Hodna Basin geomorphologic area, northeastern Algeria (M'Sila province). The Mediterranean climate of the region is subject to the influence of the Sahara and is characterised by wet winters and dry summers. The rainy period extends from October to May, and the dry season usually extends until August. The average annual rainfall is approximately 340 $\mathrm{mm}$ (for the period 1973-2010) (see information in Benkadja et al., 2012).

The K'sob river watershed drains an area of $1.484 \mathrm{~km}^{2}$ and is located between $5^{\circ} 06^{\prime} 09^{\prime \prime} \mathrm{E}$ $4^{\circ} 34^{\prime} 37^{\prime \prime} \mathrm{E}$ and $35^{\circ} 33^{\prime} 52^{\prime \prime} \mathrm{N}-36^{\circ} 18^{\prime} 45^{\prime \prime} \mathrm{N}$. The land use in this watershed consists primarily of cereal cultivation $(55 \%$ of the surface area of the basin), and reforestation programmes are being implemented in approximately $10 \%$ of the area. The hydrological regimes of the fluvial systems in the K'sob basin are characterised by a high degree of spatial and temporal variability. The $\mathrm{K}$ 'sob river, which brings water to the area and is the focus of agricultural activity in the area (Bahlouli et al., 2012), showed an average annual water discharge of $0.89 \mathrm{~m}^{3} \mathrm{~s}^{-1}$ during 1973-2010 (Benkadja et al., 2012).

The K'sob dam (15 km NE of M'Sila town) was constructed on the K'sob river between 1935 and 1940 for agricultural purposes. The gradual silting of the reservoir is a concern because the resulting decrease in capacity has raised questions about the efficiency of the reservoir. The maximum capacity of the reservoir presently allows less than $25 \mathrm{hm}^{3}$ of regularised water volume (230 ha of surface area). However, the irrigated area currently does not exceed 6250 ha (Benkadja et al., 2012).

\section{Sampling method}

During the study period (September 2010 to August 2011), monthly information was compiled

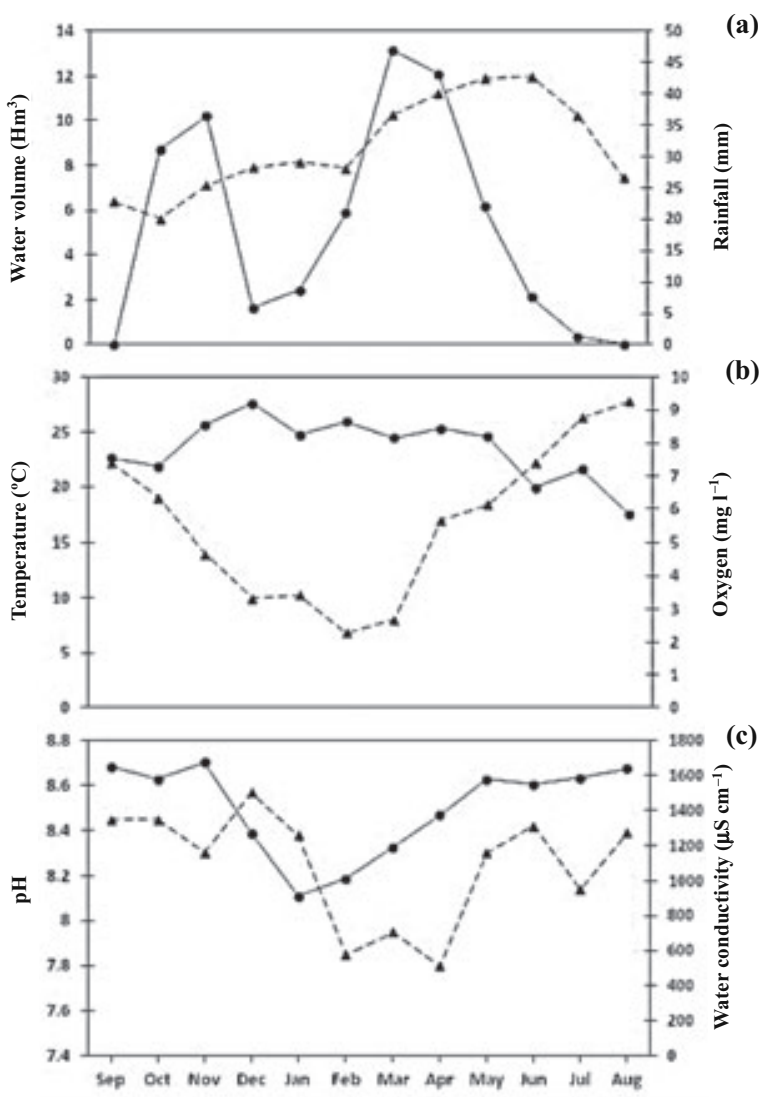

Figure 1. Monthly variation in the environmental parameters of the K'sob reservoir. (a) Water volume (black triangles) and rainfall (black points); (b) Water temperature (black triangles) and dissolved oxygen (black points); (c) pH (black triangles) and water conductivity (black points). Variación mensual en los parámetros ambientales del embalse de K'sob. (a) Volumen de agua almacenada (triángulos negros) y precipitación (puntos negros); (b) Temperatura del agua (triángulos negros) y oxígeno disuelto (puntos negros); (c) pH (triángulos negros) y conductividad del agua (puntos negros).

on the variation in several abiotic factors (Fig. 1). The monthly variations in rainfall and in the water volume of the reservoir were provided by the weather station and monitoring systems located at the K'sob reservoir. The rainfall data showed an annual value of $224.2 \mathrm{~mm}$ and confirm the seasonal climatic variations mentioned above. However, there was no correlation between rainfall and the water volume of the reservoir because of the operational pattern of the dam. During a portion of the dry months, this man-made lake stores water. The stored water is then used in accordance with agricultural needs. 
Water temperature, dissolved oxygen, $\mathrm{pH}$ and conductivity were measured near the surface (0.5 m depth) at five points distributed throughout the study area. Water temperature showed a common annual pattern of variation in the region, with maxima in summer (August $28.6^{\circ} \mathrm{C}$ ) and minima at the end of winter (February $6.6^{\circ} \mathrm{C}$; March $8{ }^{\circ} \mathrm{C}$ ). Dissolved oxygen showed an annual mean value of $7.8 \mathrm{mg}^{-1}$; however, a long period of depletion was observed from June through August (Fig. 1). Lastly, the variations in $\mathrm{pH}$ and water conductivity were, most likely, affected by the rainfall events. The average conductivity was $1417.8 \mu \mathrm{S} \mathrm{cm}^{-1}$ and remained quite stable during much of the study period. However, a period of low values (December to March, $1095.6 \mu \mathrm{S} \mathrm{cm}^{-1}$ ) occurred, primarily due to the first rainfall event.

Luciobarbus callensis $(63.5 \%$ of captures during the study period) is the only native species in the reservoir, coexisting with Cyprinus carpio L. $(21.5 \%)$, Squalius cephalus (L.) $(<1 \%)$, Oreochromis niloticus (L.) (<1\%), Hypophthalmichthys molitrix (Valenciennes) (1.8\%), Hypophthalmichthys nobilis (Richardson) (12.3\%) and Gambusia holbrooki Girard (high abundance in shallow areas).

A total of 438 specimens were collected in monthly sampling between September 2010 and August 2011. The fishing gear used by the fishermen consisted of two trammels (each approximately $50 \mathrm{~m}$ long). The nets were oriented in a transverse direction relative to the edge of the reservoir. Sampling began between 2 and 3 p.m. and ended the following morning, resulting in a minimum soaking time of 18-20 hours.

The captured specimens were preserved in neutralised formaldehyde solution (7\%) and transported to the laboratory, where their fork length (FL, $\pm 0.1 \mathrm{~mm}$ ), standard length (SL, $\pm 0.1 \mathrm{~mm})$ and total weight $(\mathrm{TW}, \pm 0.1 \mathrm{~g}$ ) were recorded. Well-preserved specimens were dissected to obtain eviscerated weight $(\mathrm{EW}, \pm 0.1 \mathrm{~g})$ and to determine their sex by direct observation of the gonads. The annual reproductive cycle was generally interpreted according to previous studies of the species (Kraiem, 1997; Aberkane \& Iguer-Ouada, 2011) and completed with direct observations of the gonads.

\section{Biological traits and data analysis}

The total number of individuals caught by the trammels was counted and expressed as catch per unit effort (CPUE), where 1 unit of effort represented a passive trammel in place for $24 \mathrm{~h}$. The data were logarithmically transformed to allow statistical comparisons. Monthly, seasonal and size differences in sex ratio were analysed with a Chi-squared test. The significance level of the test was $p \leq 0.05$.

Age and population structure were determined with two methods based on bony structures (scales) and length-frequency distributions. Scales (6-10) below the first radius of the dorsal fin and above the lateral line were removed from each specimen. These scales were cleaned using $8 \% \mathrm{NaOH}$ and used for age determination. The length-frequency distribution of the samples was studied over separate short periods of time (monthly and seasonal periods) to reduce the effects of seasonal growth.

Over a defined period of time, the specific growth rate (g) (Wootton, 1998) was calculated as follows:

$$
g_{L}=\left(\log _{e} \mathrm{FLf} \mathrm{FLi}^{-1}\right) t^{-1}
$$

and

$$
g_{E W}=\left(\log _{e} \mathrm{EWf} \mathrm{EWi}^{-1}\right) t^{-1}
$$

where FLf and EWf are the final FL and final EW, respectively, FLi and EWi are the initial FL and initial $\mathrm{EW}$, and $t$ is the time interval.

The specific growth rate was expressed as a percentage per unit time, i.e., GFL $=100 g_{L}$ and $\mathrm{GEW}=100 g_{\text {EW }}$.

The relationships (log-transformed data) between length (FL, SL) and weight (TW, EW) were calculated for all specimens and for males and females separately. The statistical significance of the differences between these relationships was verified with an analysis of covariance (ANCOVA). The somatic condition ( $\mathrm{Kr}$ index) was analysed by specifying the residual values obtained from the FL-EW relationships (logtransformed data), thus removing body length 

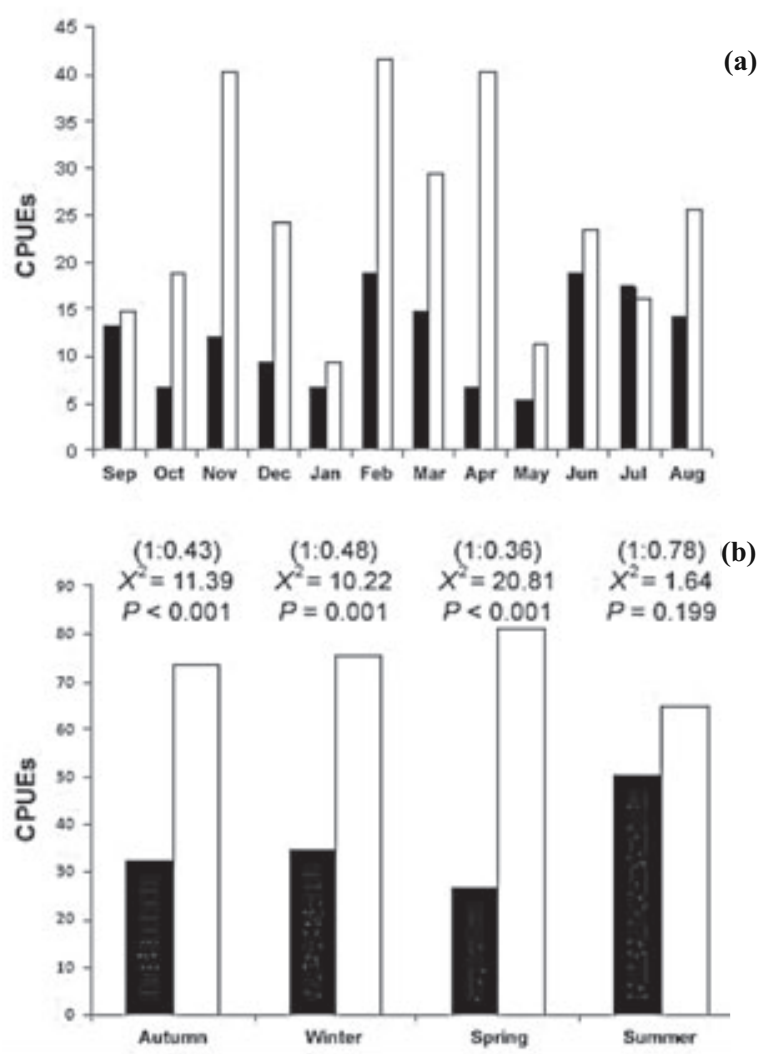

Figure 2. Catch per unit effort (CPUE) of Luciobarbus callensis in the K'sob reservoir. Captures per month (a) and season (b) with sex ratio (males:females) in brackets (chi-square statistics included). Males (white bars) and females (black bars). Capturas por unidad de esfuerzo de Luciobarbus callensis en el ambalse de K'sob. Capturas por mes (a) y estación (b) con los valores de sex-ratio machos:hembras entre paréntesis (Incluidos los estadísticos de la prueba de Chi cuadrado). Machos en barras blancas y hembras en negras.

effects (Sutton et al., 2000). The cyclic pattern of the somatic condition and the variation of somatic condition relative to fish size were indexed by the residuals from these regressions.

The statistical analyses were performed with the SPSS v. 15.0 (SPSS, Chicago, IL, USA) software package.

\section{RESULTS}

\section{Abundance and sex ratio}

A total of 438 specimens were caught during the study period, comprising 290 males (66.2\%) and 148 females $(33.8 \%)$. The overall ratio of males to females was dominated by males, with a significant difference from 1:1 (sex ratio 1:0.51; chi-square test $\left.\chi^{2}=45.39, p<0.001\right)$.

The temporal pattern of CPUE estimates for Luciobarbus callensis showed great monthly variation. However, no significant seasonal changes were found in total abundance (KruskalWallis test, $H=0.167, p=0.98$ ) (Fig. 2a). The maximum CPUE occurred in February (60.3) and the minimum values in January (16.1) and May (16.7). The abundance of males was significantly correlated with the total abundance (Pearson correlation, $r=0.94, p<0.001)$. The abundance of males also reached a maximum in February (CPUE $=41.5)$ and showed lower values during the summer (Fig. 2b). In contrast, the abundance of females was highest in summer, with the maximum value in June (18.7).

The total abundance and sex ratio were both similar from autumn 2010 to spring 2011, and males were significantly dominant during these seasons (Fig. 2b). The highest total abundance $(\mathrm{CPUE}=115.2)$ occurred in summer, with a substantial increase in the abundance of females. As a result of this increase, the sex ratio did not differ significantly from 1:1 (Fig. 2b). The sex ratio differed significantly among seasons (chisquare test $\chi^{2}=8.27$, d.f. $=3, p=0.041$ ) due to the summer increase in the abundance of females.

During the study period, only one bivariate relationship was detected between the environmental variables and abundance data. The abundance of females showed a significant positive correlation with rainfall (Pearson correlation, $r=0.73, p=0.007$ ).

The number of females was greater in the older age classes, 17 males to 28 females in individuals older than $7+$ and no difference between sexes in the 7+ age class (Fig. 3). In the younger specimens, however, the number of males was significantly greater than the number of females.

\section{Age and size structure}

Due to the presence of false annuli in the scales and because annuli take several months to form, it was difficult to determine age classes for all 


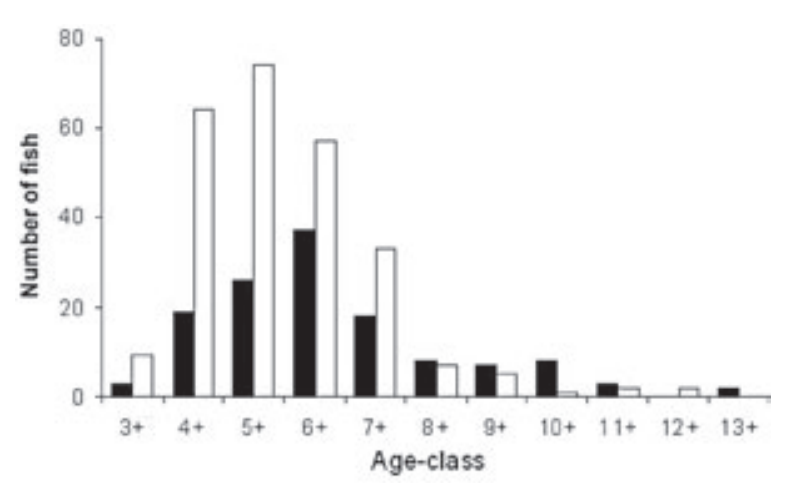

Figure 3. Age frequencies of males (white bars) and females (black bars) of the specimens caught in the K'sob reservoir during the study period. Distribución de frecuencias de machos (barras blancas) y hembras (barras negras) de los individuos capturados en el embalse de K'sob durante el periodo de estudio.

specimens. The number of suitable specimens for age-class determination was $385(87.8 \%$ of the total captures).

Age determination based on scale analysis identified 11 age groups ( $3+$ to $13+$ years) in females and 10 age groups ( $3+$ to $12+$ years) in males (Table 1). The maximum lengths observed were $37.0 \mathrm{~cm}$ TL $(34.6 \mathrm{~cm}$ FL) in a female caught in November (2010) and $34.2 \mathrm{~cm} \mathrm{TL}$ (31.9 cm FL) in a male caught in July (2011).
The catches of smaller individuals, which were partially influenced by the sampling gear (trammels), showed minimum sizes of $15.6 \mathrm{~cm} \mathrm{FL}$ for females and $15.5 \mathrm{~cm} \mathrm{FL}$ for males. Both of these specimens were in their fourth year of life $(3+)$. Females were significantly longer than males (mean FL of females, $23.6 \pm 0.3 \mathrm{~cm}$; mean FL of males, $21.8 \pm 0.2 \mathrm{~cm}$ ) (two-way ANOVA, $F(1,383)=28.711, p<0.001)$.

The size structure of the fish sampled from the K'sob reservoir was characterised by the dominance of the age classes between $4+$ and $7+(85.2 \%$ of all individuals) (Table 1; Fig. 3). Moreover, both sexes showed a low abundance of $3+$ and $4+$ in the autumn and summer. It is probable that this result is related to fish movements between the reservoir and the K'sob stream. In the present study, the catchability of specimens less than $15 \mathrm{~cm}$ FL was null (Fig. 4). However, smaller individuals of the study species are also uncommon in the catches obtained by local fishermen with a different type of fishing gear.

The seasonal values of the length-frequency distributions during the study period showed a consistent presence of males between $17.4 \mathrm{~cm}$ and $24.2 \mathrm{~cm}$ FL (Fig. 4) (mean FL of $4+=18.9 \pm$ $0.2 \mathrm{~cm}$; mean FL of $7+=24.6 \pm 0.1 \mathrm{~cm})$. The size range of the females during the study period was

Table 1. Age structure (percentage in each age class) in the studied population based on seasonal samples. Fork length for the total captures in each age class is shown ( $n$ is the number of fish with a clear scale reading; $m$ and $f$ indicate males and females, respectively; FL is fork length (mean $\pm 95 \%$ CL in samples with more than 3 specimens). Estructura de edad (porcentaje de cada clase de edad) obtenida en la población de estudio en muestras estacionales. Se incorpora la longitud furcal para el total de capturas de cada clase de edad (n es el número de peces con escamas válidas para su lectura; $\mathrm{m}$ y $\mathrm{f}$ indican machos y hembras, respectivamente; FL es la longitud furcal (media $\pm 95 \%$ LC en muestras con más de 3 especímenes).

\begin{tabular}{|c|c|c|c|c|c|c|c|c|c|c|c|}
\hline \multirow[b]{2}{*}{ Age } & \multicolumn{2}{|c|}{ Autumn } & \multicolumn{2}{|c|}{ Winter } & \multicolumn{2}{|c|}{ Spring } & \multicolumn{2}{|c|}{ Summer } & \multirow[b]{2}{*}{ Total } & \multicolumn{2}{|c|}{$\mathrm{FL}(\mathrm{cm})$} \\
\hline & $\mathrm{m}$ & $\mathrm{f}$ & $\mathrm{m}$ & $\mathrm{f}$ & $\mathrm{m}$ & $\mathrm{f}$ & $\mathrm{m}$ & $\mathrm{f}$ & & $\mathrm{m}$ & $\mathrm{f}$ \\
\hline $3+$ & - & - & 9.5 & 6.4 & 4.3 & 4.2 & - & - & 3.1 & $16.0 \pm 0.4$ & $16.3 \pm 1.6$ \\
\hline $4+$ & 7.3 & - & 46.0 & 48.4 & 43.5 & 8.3 & - & 3.8 & 21.6 & $17.4 \pm 0.3$ & $17.6 \pm 0.3$ \\
\hline $5+$ & 36.4 & 20.8 & 23.8 & 22.6 & 29.0 & 20.8 & 28.8 & 17.3 & 26.0 & $19.4 \pm 0.3$ & $19.9 \pm 0.6$ \\
\hline $6+$ & 34.5 & 51.2 & 14.3 & 6.4 & 8.7 & 37.5 & 31.8 & 25.0 & 24.4 & $21.0 \pm 0.2$ & $21.4 \pm 0.2$ \\
\hline $7+$ & 18.2 & 16.7 & 4.8 & 6.4 & 10.1 & 8.3 & 19.7 & 19.2 & 13.2 & $22.7 \pm 0.5$ & $22.9 \pm 0.3$ \\
\hline $8+$ & 1.8 & - & - & 3.2 & 1.4 & 12.5 & 7.6 & 7.7 & 3.9 & $24.8 \pm 0.8$ & $24.3 \pm 1.9$ \\
\hline $9+$ & 1.8 & - & 1.6 & 3.2 & - & 4.2 & 4.5 & 9.6 & 3.1 & $27.1 \pm 1.0$ & $26.9 \pm 2.3$ \\
\hline $10+$ & - & 4.2 & - & 3.2 & - & 4.2 & 1.5 & 9.6 & 2.3 & 29.3 & $29.6 \pm 0.8$ \\
\hline $11+$ & - & - & - & - & - & - & 3.0 & 5.8 & 1.3 & 30.7 & $31.0 \pm 0.3$ \\
\hline $12+$ & - & - & - & - & - & - & 3.0 & - & 0.5 & 31.7 & - \\
\hline $13+$ & - & 4.2 & - & - & - & - & - & 1.9 & 0.5 & - & 33.8 \\
\hline$n$ & 55 & 24 & 63 & 31 & 69 & 24 & 66 & 52 & 385 & 254 & 131 \\
\hline
\end{tabular}




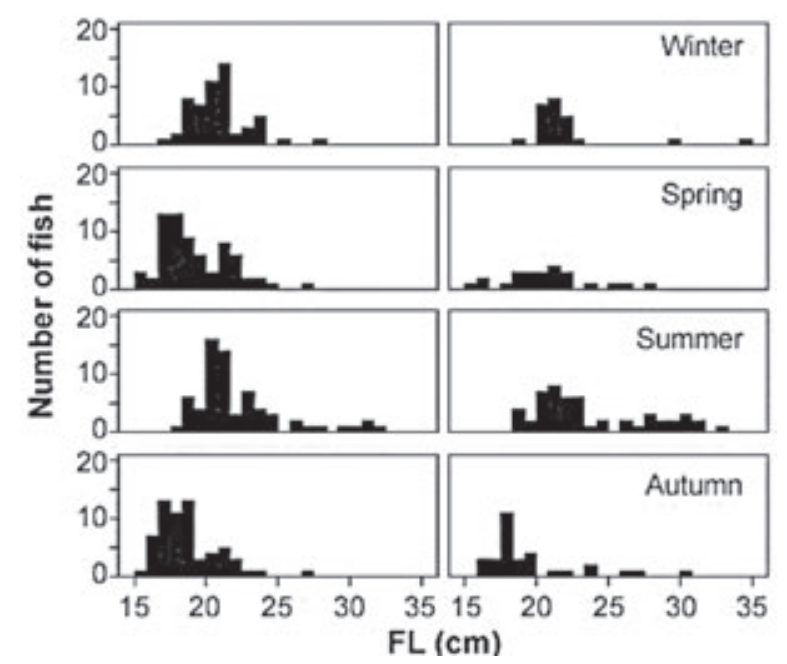

Figure 4. Length-frequency distributions of males (left) and females (right) of the specimens caught in each season in the K'sob reservoir during the study period. FL is fork length. Distribución de frecuencias por longitud de machos (izquierda) y hembras (derecha) de los individuos capturados en cada estación en el embalse de $K$ 'sob durante el periodo de estudio. FL es la longitud furcal. narrower and based on lower abundances than the size range of males (with autumn as the prime example), and the occurrence of specimens longer than $25 \mathrm{~cm}$ FL was variable in both sexes (Fig. 4).

\section{Seasonal and annual growth}

The modal progression of each cohort (age class) and the size-frequency structure were examined in the monthly and seasonal samples during the study period. Based on the data obtained from the analysed scales, annuli began to appear in February and continued to occur through March. Because formed annuli were found in the majority of individuals caught in March, the transition from winter to spring (from February to March) was considered a birth month.

The annual and seasonal growth rates were determined using the mean length (FL) and eviscerated weight (EW) increments of the different cohorts (age classes) captured during the study

Table 2. Seasonal and annual growth rates (\%) in fork length (GFL) and eviscerated weight (GEW) of established cohorts. Only growth rates with significant differences in mean values $(p<0.05)$ between seasons in the same cohort and between cohorts are presented ( $n$ s indicates non-significant differences in growth rate). Tasas de crecimiento estacional y anual (\%) obtenida en longitud furcal (GFL) y en peso eviscerado (GEW) de cohortes establecidas. Únicamente se presentan las tasas con diferencias significativas de los valores medios entre estaciones dentro de una misma cohorte y entre cohortes (ns indica diferencias no significativas en las tasas de crecimiento).

\begin{tabular}{|c|c|c|c|c|c|c|}
\hline \multirow[b]{2}{*}{ Age class } & \multicolumn{2}{|c|}{ autumn-winter } & \multicolumn{2}{|c|}{$\begin{array}{c}\text { Seasonal growth rates } \\
\text { winter-spring }\end{array}$} & \multicolumn{2}{|c|}{ spring-summer } \\
\hline & GFL & GEW & GFL & GEW & GFL & GEW \\
\hline \multicolumn{7}{|l|}{ Males } \\
\hline 2007 Cohort (4+) & $n s$ & $n s$ & 12.74 & 24.95 & $n s$ & $n s$ \\
\hline 2006 Cohort $(5+)$ & $n s$ & $n s$ & 11.63 & 31.18 & $n s$ & $n s$ \\
\hline 2005 Cohort $(6+)$ & $n s$ & $n s$ & $n s$ & 18.09 & $n s$ & $n s$ \\
\hline 2004 Cohort $(7+)$ & $n s$ & $n s$ & no-data & no-data & $n s$ & $n s$ \\
\hline \multicolumn{7}{|l|}{ Females } \\
\hline 2007 Cohort (4+) & no-data & no-data & 16.76 & 30.19 & $n s$ & $n s$ \\
\hline 2006 Cohort $(5+)$ & $n s$ & $n s$ & 8.59 & 31.35 & $n s$ & $n s$ \\
\hline 2005 Cohort $(6+)$ & $n s$ & $n s$ & 4.13 & $n s$ & $n s$ & $n s$ \\
\hline 2004 Cohort $(7+)$ & $n s$ & $n s$ & $n s$ & $n s$ & $n s$ & $n s$ \\
\hline
\end{tabular}

Annual growth rates

\begin{tabular}{lcccc} 
& \multicolumn{2}{c}{ Males } & \multicolumn{2}{c}{ Females } \\
& GFL & GEW & GFL & GEW \\
\hline 2006 Cohort & 11.01 & 22.42 & 12.13 & 24.41 \\
2005 Cohort & 7.84 & 24.55 & 6.00 & 23.15 \\
2004 Cohort & 7.37 & 17.04 & 7.63 & 15.21 \\
\hline
\end{tabular}


period. This analysis was restricted to $4+, 5+$, $6+$ and $7+$ fish because the estimated mean FLs and EWs for these age classes were obtained from a sample of adequate size, greater than 10 specimens for each age group.

The growth rates differed little between seasons (Table 2). Non-significant growth rates occurred from autumn to winter and from spring to summer. After the winter, the growth period was short (2-3 months) during the spring, and the data suggested a long non-growing period during the remainder of the annual cycle. The seasonal growth rates tended to decrease with age and were significantly lower in the $6+$ and $7+$ age classes (2004 and 2005 cohorts; Table 2).

Among the most abundant age classes in the sample, the annual growth in length during the period from autumn 2010 to summer 2011 was higher in the younger cohorts, but only in the transition from $4+$ to $5+(2006$ cohort; males GFL $=11.01 \%$, females GFL $=12.13 \%)(\mathrm{Ta}-$ ble 2). However, the growth rate in EW was also higher in the transition from 5+ to 6+ (2005 cohort, males GEW $=24.55 \%$, females GEW = $23.15 \%$ ) (Table 2). This result could reflect a qualitative change in body condition. The annual growth rates also decreased with age (Table 2).

\section{Somatic condition}

The relationships between FL and EW (dependent variable) showed the best fit between length and weight (regression analysis $p<0.05$ ) and were estimated separately for total specimens, males and females. However, there were no significant differences between sexes (ANCOVA $F(1,380)=0.003, p=0.958$ for the slope $)$, and no group showed differences over time in these relationships (season as a factor; total specimens ANCOVA $F(3,380)=1.353, p=0.257$ in the slope). Therefore, the FL-EW relationship was used for all individuals jointly $(b=2.53 \pm 0.11,95 \%$ $\mathrm{CL}, r^{2}=0.93$ ) to obtain the standardised residuals.

Significant changes in the temporal variation of somatic condition $(\mathrm{Kr})$ were found for males (Kruskal-Wallis test; $H=43.49$, d.f. $=11, p<$ $0.001)$ and females $(H=57.07$, d.f. $=11, p$ $<0.001)$. A similar cycle was evident in both se-

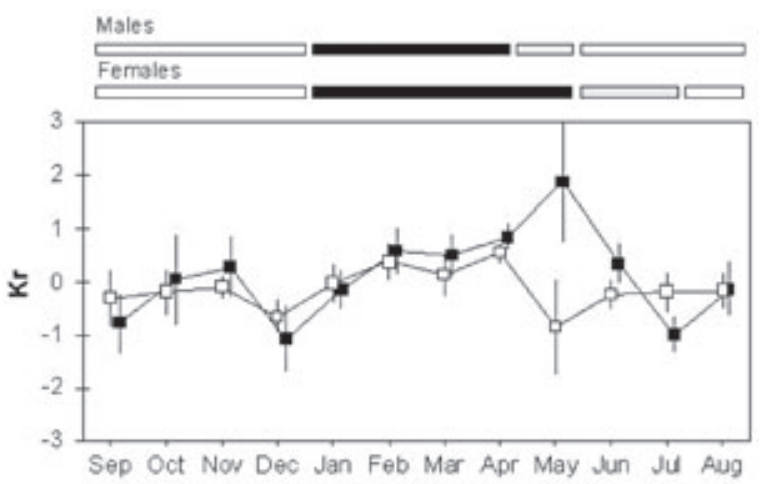

Figure 5. Temporal changes in somatic condition of the studied population in the K'sob reservoir. Data values for samples of five or more fish (mean $\pm 95 \% \mathrm{CL}$ ). Males (white squares) and females (black squares). Marks separate the defined phases of the annual cycle: phase I (black bars), phase II (grey bars) and phase III (white bars) (see main text). Cambios temporales en la condición somática de la población de estudio localizada en el embalse de K'sob. Valores de muestras con 5 o más individuos (media $\pm 95 \%$ LC), machos en cuadros blancos y hembras en negros. Las marcas separan las fases establecidas en el ciclo anual: fase I (barras negras), fase II (barras grises) y fase III (barras blancas).

xes although a significant difference between sexes, with the lowest values for males and the highest for females, was observed in the May values (Fig. 5).

Three phases could be identified in the condition cycle. Phase I (increased and high $\mathrm{Kr}$ values) extended from January to April in males and was one month longer in females (from January to May) (Fig. 5), primarily coinciding with spring and reaching maximum values just at the end of this phase (in the April sample for males, $\mathrm{Kr}=0.54 \pm 0.19$; in the May sample for females, $\mathrm{Kr}=1.85 \pm 0.98$ ). Phase II (decreased $\mathrm{Kr}$ values) was clearly evident at the end of the spring in males and showed a less marked drop in $\mathrm{Kr}$ from May to July in females, coinciding with the species' spawning period in this area (unpublished data). Lastly, Phase III occurred during summer and autumn, when the Kr condition values remained relatively constant, increasing only slightly until the December sample.

No relationship between age and somatic condition was found in either sex (Spearman correlation for $\mathrm{Kr}$ values, males $p=0.331$; females $p=0.293$ ). Significant age-related variations were found in the $\mathrm{Kr}$ values for males (Kruskal- 
Wallis test; $H=6.19$, d.f. $=7, p=0.52)$ and females $(H=7.99$, d.f. $=7, p=0.33)$.

\section{DISCUSSION}

The volume of dammed waters is large in the Maghreb ecoregion (Benkadja et al., 2012; Kara, 2012). The former predominance of lotic systems in the ecoregion has shifted to a predominance of lentic environments. This change has many implications for freshwater fishes, whose evolutionary life history strategies are adapted to aquatic systems - Mediterranean streams having characteristics diametrically opposed to those of the ecological theatre in which these fishes have been placed through human activity (Granado-Lorencio, 2000). When a dam is constructed, the lotic system is replaced by an ecosystem with completely different characteristics. For example, the thermal gradients and anoxia present in many reservoirs make these resources unavailable to stream fish (Encina et al., 2006). Only populations of stream fish with appropriate adaptive strategies can invade these new ecosystems and attempt to adjust their life styles to the new conditions. Certain barbels in the circum-Mediterranean area have life styles that are a priori suitable for life in stressed or fluctuating environments and are thus potentially capable of colonising new artificial environments, such as reservoirs (Encina et al., 2006; Hladik et al., 2008). However, the only species that will become established and persist in the new fish assemblage of the reservoir are those with the ability to exploit the new trophic resources (Encina et al., 2004) or those able to develop a good level of recruitment, either by completing their life cycle within the reservoir or by sustaining the populations by maintaining a flow of individuals between the reservoir and the streams that flow into it (Rodríguez-Ruiz \& Granado-Lorencio, 1992).

In the man-made K'sob lake, Luciobarbus callensis is known to be one of the most abundant species and to show a certain degree of stability in its seasonal densities. In general, monitoring of CPUE does not provide a good estimate of absolute fish densities. Instead, it provides information on relative changes in the fish populations. In the absence of better indicators, seasonal catchability at a standard level of effort could appropriately reflect variations in fish abundance at the site level. The relative abundance of the studied population showed clear monthly variation. The seasonal feeding rhythms of the species (Kraiem, 1996) could affect the catches, and the K'sob reservoir also presents a heterogeneity of habitats (i.e., damwater, tailwater) and a functional pattern that must determine the spatiotemporal distribution of the species. In man-made lakes in the Maghreb region, it has previously been shown (Djemali et al., 2010) that the abundance of a fish population and the use of space by the population within a reservoir corresponds primarily to environmental factors determined by the limnological cycle and the management of the water body. We found no significant relationships between environmental variables and the abundance of the species except for the correlation between rainfall and the relative abundance of females. Most likely, this general lack of evidence for such relationships was a result of the number of sampling events or of the possibility that any relationships were obscured by the complexity of the ecological interactions. However, our fish sample showed significant seasonal changes in sex ratio and size structure that could be governed by both intrinsic temporal patterns and ecological factors. An important characteristic of cyprinids, which is well-documented for the genera Barbus and Luciobarbus in Mediterranean systems (Rodríguez-Ruiz \& Granado-Lorencio, 1992) and is, most likely, reflected in the growth traits of Luciobarbus callensis in the $\mathrm{K}$ 'sob watershed system is the cyclic reproductive migration between reservoirs and the rivers that flow into them. Limited surveys have confirmed that the target species spawns in the headwaters of the K'sob stream (Mimeche pers. com.), the only river draining into our man-made lake. Although the species can also reproduce in reservoirs (Ould-Rouis et $a l ., 2012$ ), it shows strong specific preferences for streams as breeding habitats (Berrebi et 
al., 1995). As a lithophile spawning species, barbels prefer well-oxygenated and running reaches of river with gravel substrates (Kottelat \& Freyhof, 2007). Bouhbouh (2002) found a correlation between the relative abundance and the reproductive cycle of Luciobarbus callensis in the Allal El Fassi reservoir. Additional studies with a specific sampling design appropriate for detecting the species' movement within the reservoir and with samples that include sections of the K'sob stream are needed before any firm conclusions can be drawn.

The lifespan of the population inhabiting the K'sob watershed was long, with at least 14 age groups observed (maximum age class: 13+). Although we did not catch any specimens younger than $3+$ at the sampling site, their occurrence in the reservoir has been confirmed by local fishermen based on occasional catches of small-sized individuals. In contrast, small individuals of the species are common in the upstream reaches of the K'sob stream, where local fishermen have frequently caught them (Mimeche pers. com.). The long lifespan of the reservoir populations and the occurrence of younger specimens primarily in the streams are in agreement with the patterns observed in several cyprinid populations previously studied in watershed systems throughout the Mediterranean area (Encina et al., 2006). Barbels migrate up-river in spring for reproduction and to exploit the trophic resources of the environment with maximum efficiency. This species maintains the migratory cycle after it has colonised the reservoir (Encina \& Rodríguez-Ruiz, 2002). The dominance of midsize fish in our captures, as also found in a study of the population of Hamiz dam (Ould-Rouis et al., 2012), could also be correlated with the proximity of these populations to a higher-order tributary and facilitated by the affinity of the species with stream conditions (Kraiem, 1989).

The age structure of the Luciobarbus callensis specimens collected in the K'sob reservoir differs slightly from that observed in the Allal El Fassi reservoir (Bouhbouh, 2002). The maximum size of the captured fish is also similar to that of fish from Sidi Salem and Joumine reservoirs (Kraiem, 1996; M'Hadhbi \& Boumaiza, 2008) and slightly shorter than that of fish from Hamiz dam (Ould-Rouis et al., 2012). All of these localities are farther north than the site of the present study. However, the age structure of the study specimens from the K'sob reservoir differs significantly from that of previously studied populations inhabiting streams, where fewer age groups and a smaller maximum size have been detected (Table 3). Several studies of cyprinid populations in reservoirs indicate that changes have occurred in the biology of these fish (Encina et al., 2006). For example, differences in growth traits have been noted: the specimens within a reservoir attain a greater size than those inhabiting the adjacent stream and live longer.

In the studied population, an annulus was formed at the beginning of spring (FebruaryMarch). This finding is similar, to a certain ex-

Table 3. Maximum total length and age class observed in studies of Luciobarbus callensis by other authors (* data in fork length; $m$ and $f$ indicate males and females, respectively). Longitudes totales máximas y clases de edad observadas en otros estudios sobre Luciobarbus callensis ( $*$ datos en longitud furcal; $\mathrm{m} y \mathrm{f}$ indican machos y hembras, respectivamente).

\begin{tabular}{lccc}
\hline Locality (Area) & Length $(\mathrm{cm})$ & Age class & Reference \\
\hline K'sob reservoir (NE Algeria) & $37(m)$ & $13+$ & This study \\
Hamiz dam (N Algeria) & $34.2(f)$ & $12+$ & Ould-Rouis et al. $(2012)$ \\
Sebaou stream (N Algeria) & $46(f)$ & - & Penczak \& Molinski (1984) \\
Béja stream (N Tunisia) & 16.2 & $3+$ & Kraiem et al. $(1986)$ \\
Ghezalla stream (N Tunisia) & 26 & $5+$ & Kraiem et al. $(1986)$ \\
Sidi Salem reservoir (N Tunisia) & 25 & $4+$ & Kraiem (1996) \\
Joumine reservoir (N Tunisia) & 30 & - & M'Hadhbi \& Boumaiza (2008) \\
Allal El Fassi reservoir (N Morocco) & 32 & $10+$ & Bouhbouh (2002) \\
\hline
\end{tabular}


tent, to the results from populations of barbels studied at similar latitudes in the Mediterranean area. However, the period of annulus formation for the southern Iberian barbel [Luciobarbus sclateri (Günther)] at a slightly greater northern latitude than our study site was the middle or the end of spring (Herrera \& Fernández-Delgado, 1992; Torralva et al., 1997).

The results of this study show that Luciobarbus callensis in the study population grow rapidly during the first three years of life, attaining approximately $50 \%$ of their maximum length (females $3+\mathrm{TL}=17.9 \pm 0.4 \mathrm{~cm}$; males $3+$ $\mathrm{TL}=17.5 \pm 0.3 \mathrm{~cm})$. Although no data on the age of maturity are available, our observations (all fish captured were mature specimens) indicate that the rapid growth discussed above occurred primarily before the first spawning. This result implies that the annual increase in growth diminished markedly after sexual maturity, as also observed in certain northern Mediterranean barbels (Rodríguez-Ruiz \& Granado-Lorencio, 1992; Herrera \& Fernández-Delgado, 1992; Torralva et al., 1997; Sumer \& Povz, 1998; Miñano et al., 2000; Vasiliou \& Economidis, 2005; Oliva-Paterna et al., 2007). In fact, the annual growth rates of the middle age classes (from 4+ to $7+$ ) in the K'sob population were not very high. In these mature middle-aged individuals, the decrease in annual growth observed with increasing age was also observed in the pattern of seasonal growth.

The annual growth pattern fits a sinusoid-like curve, with the only growth period occurring from the end of winter to spring immediately prior to the reproductive period. Growth virtually ceases during the remainder of the year. The study population is found at a latitude where temperature most likely allows growth to occur for more than three months per year, as has been observed in several Iberian cyprinids (Herrera \& Fernández-Delgado, 1992; Torralva et al., 1997). Nevertheless, the ecological conditions of the K'sob river - reservoir system could be limiting the period of growth. The hydrological cycle of the K'sob stream is typical of the Mediterranean area, where flow ceases in the summer and the river system consists primarily of small isolated pools. During this period, the fish in our study specimens of our target species have two possibilities, population can become concentrated in these stream habitats or can return to the reservoir to avoid the harsh conditions in the stream at the end of summer. Findings from Hamiz dam (Ould-Rouis et al., 2012) and our data showed that a substantial fraction of the adults most likely return to the reservoir. It is conceivable that the K'sob reservoir offers a more stable environment than the highly variable environment of the stream that flows into it. However, this man-made lake is highly fluctuating and unpredictable for fish populations because its management for agricultural purposes has important effects on the hydrological cycle. Moreover, because the watershed is facing severe soil degradation (Benkadja et al., 2012), heavy silting has affected the K'sob dam, and suspended sediment also occurs commonly in the water during certain seasons. Hence, environmental stress in the population could be high, and significant changes may occur in life history traits in association with these environmental conditions. Accordingly, a high growth rate during the first years of life followed by a decrease and only a brief seasonal growth period per year subsequent to the initial phase may be adaptations to increase fitness.

Studies of the variation in the condition factor or other related indices of body energy content have generally been used in barbels as indicators of seasonal physiological status and changes in body composition (Encina \& Granado-Lorencio, 1997). In our opinion, the temporal variation in somatic condition observed in this study reflected the effects of both environmental seasonality and the reproductive cycle of the species, as was the case in the previous study of Hamiz dam (Ould-Rouis et al., 2012). At the end of spring (May), when spawning begins (Aberkane \& Iguer-Ouada, 2011), variations in somatic condition were observed. It is possible that these variations were related to the transfer of energy to the gonads. This pattern is similar to those found in other barbel species (Rodríguez-Ruiz \& Granado-Lorencio, 1992; Herrera \& FernándezDelgado, 1992; Torralva et al., 1997). Moreover, 
the decrease in somatic condition during the summer may be a result of the severe droughts occurring during the summer in the Mediterranean area. These droughts produce unfavourable conditions for fish survival and result in a depletion of stored energy. Such depletion is also associated with the final phases of spawning activity and the high metabolic demands occurring during this period (Encina \& Granado-Lorencio, 1997; Oliva-Paterna et al., 2003).

According to Berrebi et al. (1995), the zone inhabited by barbels in the northeastern Maghreb region is not characterised by a well-defined altitude or stream slope. Accordingly, the entire watershed can be considered a barbel ecosystem. In fact, the high capacity of the species to inhabit both natural and artificial systems and to adapt to a great range of environmental conditions has been previously noted (Kraiem \& Pattee, 1988; Kraiem, 1996). In the K'sob reservoir, an old man-made lake, we detected changes in abundance, population size and age structure, growth rates and somatic condition that can be associated with both the historical evolution of the water mass and the current management of the reservoir. Moreover, the growth traits of the studied population will be strongly affected by the hydrological natural regimes of the K'sob basin, which are characterised by high spatial and temporal variability. Among the native species of the Maghreb that have been able to colonise reservoir ecosystems, we consider Luciobarbus callensis one of the most successful. The life history plasticity of the species may be the reason for its success. Nevertheless, the paradigm of invasive species and overfishing could indicate threats that must be influencing its status and should be studied.

\section{ACKNOWLEDGEMENTS}

A portion of the financial support for this study was provided by University of M'Sila (Algeria). F. Mimeche held two fellowships from the Ministere de L'Enseignement Superieur et de la Recherche Scientifique Algérienne to support work conducted in the Department of Zoology and Anthropology, University of Murcia (Spain).

\section{REFERENCES}

ABERKANE, B. \& M. IGUER-OUADA. 2011. Étude de la reproduction du Barbeu (Barbus barbus callensis). Éditions Universitaires Européenes, France.

AZEROUAL, A., A.J. CRIVELLI, A. YAHYAOUI \& M. DAKKI. 2000. L'ichtyofaune des eaux continentales du Maroc. Cybium, 24(Suppl. 3): 17-22.

BACHA, M. \& R. AMARA. 2007. Les poissons des eaux continentales d'Algérie. Étude de l'ichtyofaune de la Soummam. Cybium, 31(3): 351-358.

BAHLOULI, F., A. AMROUNE, S. TELLACHE, A. TIAIBA, A. ZEDAM \& A. SLAMANI. 2012. Agro-ecological study of the plain of M'Sila, Western Nothern zone of the basin Hodna, Wilaya of M'Sila, Algeria. Agricultural Journal, 7(1): $10-16$.

BENKADJA, R., A. HATTAB, N. MAHDAOUI \& C. ZEHAR. 2012. Assessment of soil losses and siltation of the K'sob hydrological system (semiarid area-East Algeria). Arabian Journal of Geoscience. doi 10.1007/s12517-012-0653-z.

BERREBI, P., M. M. KRAIEM, I. DOADRIO, S. EL GHARBI \& G. CATTANEO-BERREBI. 1995. Ecological and genetic differentiation of Barbus callensis populations in Tunisia. Journal of Fish Biology, 47: 850-864.

BOUHBOUH, S. 2002. Bio-écologie de Barbus callensis (Valencienne 1842) \& Barbus fritschi (Günther 1874 ) au niveau du réservoir Allal El Fassi (Maroc). Doctoral Thesis. Université Sidi Mohamed Ben Abdelah, Fes, Morocco.

COOKE, S. J., C. PAUKERT \& Z. HOGAN. 2012. Endangered river fish: factors hindering conservation and restoration. Endangered Species Research, 17: 179-191.

DJEMALI, I., R. TOUJANI \& J. GUILLARD. 2008. Hydroacoustic fish biomass assessment in man-made lakes in Tunisia: horizontal beaming importance and diel effect. Aquatic Ecology, 43(4): 1121-1131.

DJEMALI, I., H. LAHOUAR \& R. TOUJANI. 2010. Distribution patterns of fish biomass by acoustic survey in three Tunisian man-made lakes. Journal of Applied Ichthyoly, 26: 390-396.

DOADRIO, I. 1994. Freshwater fish fauna of North Africa and its biogeography. Annales du Musée Royal de l'Afrique Centrale, 275: 21-34. 
DOADRIO, I., R. BOUHADAD \& A. MACHORDOM. 1998. Genetic differentation and biogeography in Saharan populations of the genus Barbus (Osteichthyes, Cyprinidae). Folia Zoologica, 47: 7-20.

ENCINA, L. \& C. GRANADO-LORENCIO. 1997. Seasonal changes in condition, nutrition, gonad maduration and energy content in barbel, Barbus sclateri, inhabiting a fluctuating river. Environmental Biology of Fishes, 50(1): 75-84.

ENCINA, L. \& A. RODRÍGUEZ-RUIZ. 2002. Patterns of seasonal distribution of the fish assemblage in a reservoir of recent construction. Verhandlungen des Internationalen Verein Limnologie, 28: 641-650.

ENCINA, L., A. RODRÍGUEZ-RUIZ \& C. GRANADO-LORENCIO. 2004. Trophic habits of the fish assemblage in new freshwater ecosystems: The Joaquin Costa reservoir. Folia Zoolica, 53(4): 437-449.

ENCINA, L., A. RODRÍGUEZ-RUIZ \& C. GRANADO-LORENCIO. 2006. The Iberian ichthyofauna: Ecological contributions. Limnetica, 25(1-2): 349-368.

GANTE, H. F. 2011. Diversification of circumMediterranean Barbels. In: Changing Diversity in Changing Environment, Grillo O. \& Venora G. (eds.): 283-298. InTech published online.

GARCÍA, N., A. CUTTELOD \& D. ABDUL MALAK. 2010. The status and distribution of freshwater biodiversity in northern Africa. IUCN, Gland (Switzerland), Cambridge (UK) \& Málaga (Spain).

GRANADO-LORENCIO, C. 2000. Ecología de Comunidades. El paradigma de los peces de agua dulce. Secretariado de Publicaciones de la Universidad de Sevilla, Sevilla (Spain).

HERRERA, M. \& C. FERNÁNDEZ-DELGADO. 1992: The life-history patterns of Barbus bocagei sclateri (Günther, 1868) in a tributary stream of the Guadalquivir River basin, southern Spain. Ecology of Freshwater Fish, 1: 42-51.

HLADIK, M., J. KUBECKA, T. MRKVICKA, M. CECH, V. DRAST, J. FROUZOV, E. HOHAUSOV, J. MATENA, V. MATENOV, M. KRATOCHV, J. PETERKA, M. PRCHALOV \& M. VAEEK. 2008. Effects of the construction of a reservoir on the fish assemblage in an inflow river. Czech Journal of Animal Science, 53: 537-547.

JUFFE-BIGNOLI, D. \& W.R.T. DARWALL. 2012. Assessment of the socio-economic value of freshwater species for the northern African region. IUCN, Gland (Switzerland), \& Málaga (Spain).

KARA, H. M. 2012. Freshwater fish diversity in Algeria with emphasis on alien species. European Journal of Wildlife Research, 58(1): 243-253.

KOTTELAT, M. \& J. FREYHOF. 2007. Handbook of European freshwater fishes. Kottelat, Cornol (Switzerland) \& Freyhof, Berlin (Germany).

KRAIEM, M. M. 1989. Étude comparée de la croissance de différentes populations de Barbus callensis Valenciennes 1842 (Pisces, Cyprinidae) de Tunisie. Cybium, 13(4): 365-374.

KRAIEM, M. M. 1996. The diet of Barbus callensis (Cyprinidae) in northern Tunisia. Cybium, 20(1): 75-85.

KRAIEM, M. M. 1997. Chronologie de la reproduction et cycle de développement des gonades chez Barbus callensis Valenciennes, 1842 (Pisces, Cyprinidae) de Tunisie. Bulletin Institut National des Sciences de Mar, 24 (1): 74-88.

KRAIEM, M. M \& E. PATTEE. 1988. Salinity tolerance of the barbel, Barbus callensis Valenciennes, 1842 (Pisces, Cyprinidae) and its ecological significance. Hydrobiologia, 166: 263-267.

KRAIEM, M. M., Y. BOUVET, E. PATTEE \& H. PERSAT. 1986. Étude des populations de barbeaux, Barbus callensis Valenciannes 1842, dans trois cours d'eau du nord-ouest de la Tunisie. Archive du Hydrobiologie, 107(3): 411-422.

LÉVÊQUE, C., T. ODERDORFF, D. PAUGY, M.L.J. STIASSNY \& P.A. TEDESCO. 2008. Global diversity of fish (Pisces) in freshwater. Hydrobiologia, 595: 545-567.

MACHORDOM, A. \& I. DOADRIO. 2001. Evolutionary history and speciation modes of cyprinid genus Barbus. Proceedings of the Royal Society B, 268: 1297-1306.

M'HADHBI, L. \& M. BOUMAIZA. 2008. Étude de la croissance relative du barbeau: Barbus callensis (Cyprinidae) de la retenue de barrage Joumine (Nord Tunisien). Analele Ştiinţifice ale Universităţii Al. I. Cuza Iaşi, s. Biologie animală (LIV): 245-258.

MIÑANO, P. A., F. J. OLIVA-PATERNA, C. FERNÁNDEZ-DELGADO \& M. TORRALVA. 2000. Age and growth of Barbus graellsii Steindachner, 1866 and Chondrostoma miegii Steindachner, 1866 (Pisces, Cyprinidae) in the river Cinca (Ebro river basin, NW Spain). Miscel-lània Zoológica, 23(2): 9-19. 
OLIVA-PATERNA, F. J., A. VILA-GISPERT \& M. TORRALVA. 2003. Condition of Barbus sclateri from semi-arid aquatic systems: habitat quality effects. Journal of Fish Biology, 63: 699-709.

OLIVA-PATERNA, F. J., P. A. MIÑANO, M. TORRALVA \& C. FERNÁNDEZ-DELGADO. 2007. Reproductive strategies of Barbus graellsii and Chondrostoma miegii (Pisces, Cyprinidae) in the Cinca River (NE Iberian Peninsula). Zoologica Baetica, 18: 3-20.

OULD-ROUIS, S., A. OULD-ROUIS, J.C. MICHA \& A. ARAB. 2012. Biologie de la reproduction du Cyprinidae, Barbus callensis dans le lac de barrage Hamiz (Algérie). Tropicultura, 30, 2: 88-93.

PENCZAK, T. \& M. MOLINSKI. 1984. Fish production in Oued Sebaou, a seasonal river in North Algeria. Journal of Fish Biology, 25(6): 723-732.

RODRÍGUEZ-RUIZ, A. \& C. GRANADO-LORENCIO. 1992. Spawning period and migration of three species of cyprinids in a stream with Mediterranean regimen (SW Spain). Journal of Fish Bio- logy, 41: 545-556.

SUMER, S. \& M. POVZ. 1998. Age and growth of Barbus meridionalis (Cyprinidae) from two rivers in Slovenia. Italian Journal of Zoology, 65: 237239.

SUTTON, S. G., T. P. BULT \& R. L. HAEDRICH. 2000. Relationships among Fat Weight, Body Weight, Water Weight, and Condition Factors in Wild Atlantic Salmon Parr. Transactions of the American Fisheries Society, 129(2): 527-538.

TORRALVA, M., M. A. PUIG \& C. FERNÁNDEZDELGADO, C. 1997. Effect of river regulation on the life-history patterns of Barbus sclateri in the Segura river basin (south-east Spain). Journal of Fish Biology, 51: 300-311.

VASILIOU, A. \& P. S. ECONOMIDIS. 2005. On the life-history of Barbus peloponnesius and Barbus cyclolepis in Macedonia, Greece. Folia Zoologica, 54(3): 316-336.

WOOTTON, R. J. 1998. Ecology of Teleost Fishes. Chapman \& Hall, London (UK). 